\title{
PENGARUH PENGENDALIAN INTERNAL DAN KESESUAIAN KOMPENSASI FINANSIAL TERHADAP KECENDERUNGAN FRAUD (STUDI EMPIRIS PADA PERUSAHAAN AIR MINUM TIRTA MANGKALUKU DAERAH KOTA PALOPO)
}

\author{
Kartini Wulandari \\ Jurusan Akuntansi Audit Internal, Universitas Muhammadiyah (UM) Palopo \\ Kartinwulan@gmail.com
}

\begin{abstract}
ABSTRAK
Penelitian ini bertujuan untuk mengetahui dan menganalisis pengaruh pengendalian internal dan kesesuaian kompensasi finansial terhadap tingkat kecenderungan fraud pada Perusahaan Air Minum Tirta Mangkaluku Daerah Kota Palopo. Metode penelitian ini menggunakan pendekatan survey dengan memberikan daftar pernyataan di Perusahaan Air Minum Tirta Mangkaluku Daerah Kota Palopo. Kuesioner yang dibagikan kepada responden sebanyak 80 eksamplar dan kuesioner yang dikembalikan sebanyak 65 eksamplar. Hasil survey dianalisis menggunakan regresi linear berganda. Hasil penelitian ini menunjukkan bahwa pengendalian internal dan kesesuaian kompensasi finansial secara parsial berpengaruh positif dan signifikan terhadap kecenderungan fraud di Perusahaan Air Minum Tirta Mangkaluku Daerah Kota Palopo. Keterbatasan dalam penelitian ini variabel penelitian yang digunakan hanya mempengaruhi variabel indenpenden terhadap dependen sebesar 28,4 persen sedangkan 71,6 persen dijelaskan oleh faktor lain yang tidak diteliti, menggunakan kuisioner tanpa di lengkapi dengan wawancara atau pernyataan lisan dan pengisian kuisioner tidak didampingi.
\end{abstract}

Kata Kunci: Pengendalian Internal, Kesesuaian Kompensasi Finansial dan Kecenderungan Fraud

\section{ABSTRACT}

This study aims to determine and analyze the effect of internal control and the suitability of financial compensation for the level of fraud tendencies in the Tirta Mangkaluku Drinking Water Company in Palopo City. This research method uses a survey approach by providing a list of statements in the Tirta Mangkaluku Drinking Water Company in the City of Palopo. Questionnaires were distributed to respondents of 80 exams and questionnaires were returned as many as 65 exams. Survey results were analyzed using multiple linear regression. The results of this study indicate that internal control and suitability of financial compensation partially have a positive and significant effect on the tendency of fraud in the Tirta Mangkaluku Drinking Water Company in Palopo City. Limitations in this study the research variables used only affect the dependent variable of 28.4 percent while 71.6 percent were explained by other factors not examined, using questionnaires without being equipped with interviews or oral statements and filling in the questionnaire was not accompanied.

Keywords: Internal Control, Suitability of Financial Compensation and Trendency of Fraud

\section{PENDAHULUAN}

Kecurangan akuntansi telah muncul dan berkembang di berbagai negara, termasuk di Indonesia. Kecurangan akuntansi atau fraud yang akhir-akhir ini marak terjadi di Indonesia dan menjadi pusat perhatian karena menimbulkan kerugian yang sangat besar hampir semua sektor industri. Banyak individu maupun kelompok dalam suatu lembaga yang melakukan praktik kecurangan baik sektor publik maupun sektor swasta (Usmar, 2016). Pada sektor publik kecendrungan kecurangan dilakukan dalam bentuk kebocoran Anggaran Pendapatan dan Belanja Negara (APBN), sedangkan di sektor swasta bentuk kecendrungan kecurangan terjadi dalam bentuk yang sama yaitu ketidaktepatan dalam membelanjakan sumber dana (Cendikia, 2016). 
Kecurangan dalam laporan keuangan, dibandingkan dengan bentuk kecurangan lain yang dilakukan karyawan perusahaan, biasanya memiliki dampak kerugian aset yang lebih tinggi pada perusahaan yang menjadi korban. Kecurangan akuntansi pada umumnya disebabkan oleh dorongan untuk memanfaatkan kesempatan atau dapat pula disebabkan tekanan dari manajemen untuk melakukan penyelewengan secara terstruktur. Para pelaku kecurangan selalu berusaha memanfaatkan setiap kesempatan yang ada untuk memperoleh keuntungan bagi dirinya. Akibatnya tindakan tersebut menimbulkan kerugian bagi pihak peusahaan (Usmar, 2016).

Di Indonesia sendiri kasus kecurangan akuntansi yang paling sering terjadi adalah korupsi. Dalam korupsi, tindakan yang lazim dilakukan di antaranya adalah memanipulasi pencatatan, penghilangan dokumen, dan mark-up yang merugikan keuangan negara atau perekonomian negara. Tindakan ini merupakan bentuk kecurangan akuntansi (Hidayat, 2018).

Transparency International merilis indeks persepsi korupsi negara-negara di dunia untuk tahun 2017. Transparency International menyimpulkan belum ada banyak perkembangan dari negaranegara ini untuk mengakhiri korupsi. Peringkat pertama diduduki Selandia Baru dengan nilai 89. Nilai negara ini turun 1 poin dari tahun lalu. Sementara itu, peringkat terbawah atau 180 diduduki Somalia dengan nilai 9. Nilai negara ini turun 1 poin dari tahun lalu. Indonesia ada di peringkat ke 96 dengan nilai 37. Selain Indonesia, ada Brasil, Kolombia, Panama, Peru, Thailand, dan Zambia di peringkat dan nilai yang sama. Indeks persepsi korupsi Indonesia dari 2016 ke 2017 sama, yaitu 37, tapi peringkatnya turun. Pada 2016, Indonesia berada di peringkat ke 90 (Detiknews.com).

Kasus korupsi di Sulawesi Selatan juga masih banyak terjadi salah satunya adalah kasus korupsi instalasi pengolahan air PDAM yang dilakukan oleh, Ilham Arief Sirajuddin Wali Kota Makassar yang didakwa merugikan negara sebanyak Rp 45,9 Miliar pada 7 Mei 2014. Terdakwa melakukan perbuatan memperkaya diri sendiri atau orang lain yakni memperkaya diri sebesar Rp 5,5 Miliar dan Direktur PT Traya Tirta dalam kasus yang sama merugikan negara sebesar Rp 40,33 Miliar. Atas tindak pidana tersebut, Ilham dijerat Pasal 2 ayat (1) atau Pasal 3, Undang-Undang Nomor 20 Tahun 2001 tentang Pemberantasan Tindak Pidana Korupsi juncto Pasal 55 ayat (1) KUHP (Cnnindonesia.com).

Tindakan fraud yang dilakukan suatu pihak biasanya disebabkan oleh keinginan untuk memaksimalkan keuntungan pribadi. Kecurangan sering dikaitkan dengan penegakan hukum, pengendalian internal dan pemberian kompensasi. Keefektifan pengendalian internal penting dalam pelaksanaan suatu kegiatan untuk mencapai tujuan perusahaan atau instansi. 
Ketidakefektifan pengendalian internal akan dapat membuka kesempatan bagi pegawai untuk melakukan tindakan yang menyimpang atau kecurangan (fraud) karena pegawai akan memanfaatkan ketidakefektifan pengendalian internal itu sebagai suatu titik lemah perusahaan untuk melakukan kecurangan (fraud). Pengendalian internal yang baik memungkinkan meminimalisir terjadinya kecurangan (Adi, 2016).

Instansi atau perusahaan harus memiliki sistem pengendalian internal yang efektif di mana setiap aktivitas-aktivitas yang dilakukan karyawan dalam instansi atau perusahaan tersebut mendapatkan pengawasan yang ketat. Dengan adanya pengendalian internal yang efektif diharapkan dapat meminimalisasikan tindakan kecurangan akuntansi dalam instansi atau perusahaan yang dapat merugikan instansi atau perusahaan itu sendiri (Usmar, 2016).

Selain pengendalian internal faktor yang dapat mempengaruhi terjadinya kecurangan akuntansi adalah kesesuaian kompensasi finansial yang mempengaruhi kecenderungan kecurangan akuntansi. Menurut Cendikia (2016), kompensasi dapat berperan dalam meningkatkan motivasi pegawai untuk bekerja lebih efektif dan produktif, sebab kompensasi adalah alat untuk memenuhi berbagai kebutuhan pegawai. Tinggi rendahnya kompensasi yang diberikan akan mempengaruhi kinerja dan kesetiaan pegawai.

Penelitian tentang pengaruh pengendalian internal dan kesesuaian kompensasi terhadap kecendrungan kecurangan akuntansi di Indonesia telah banyak dilakukan diantaranya penelitian yang dilakukan oleh Ramadhany (2017) yang meneliti pengaruh sistem pengendalian internal, asimetri informasi, kesesuaian kompensasi dan implementasi good corporate governance terhadap kecenderungan kecurangan akuntansi pada Rumah Sakit Swasta Pekanbaru. Hasil penelitiannya menunjukkan bahwa pengaruh sistem pengendalian internal, asimetri informasi, kesesuaian kompensasi dan implementasi good corporate governance berpengaruh positif terhadap kecenderungan kecurangan akuntansi. Hasil penelitian yang berbeda dilakukan oleh Aji (2018) yang meneliti tentang analisis faktor-faktor penentu kecurangan (fraud) pada Perusahaan menengah di Yogyakarta. Hasil penelitiannya menunjukkan terdapat pengaruh negatif antara etika, kesesuaian kompensasi dan gaya kepemimpinan terhadap kecurangan (fraud).

Hasil penelitian di atas terdapat ketidak konsistenan hasil antara penelitian satu dengan penelitian lainya, hal ini menyebabkan pengaruh sistem pengendalian internal dan kesesuaian kompensasi finansial terhadap kecendrungan kecurangan masih merupakan sesuatu yang menarik untuk diteliti. 


\section{TINJAUAN PUSTAKA}

\section{Fraud Diamond Theory}

Fraud diamond theory merupakan hasil modifikasi dari fraud triangle theory yang dikemukakan oleh Cressey (1953). Jika pada fraud triangle theory terdiri dari tiga elemen yaitu tekanan (incentives/pressure), kesempatan (opportunity), dan rasionalisasi, maka pada fraud diamond theory, Wolfe dan Hermanson (2004) menambahkan satu elemen kualitatif yang diyakini memiliki pengaruh signifikan terhadap fraud yakni kemampuan (capability) sehingga menjadi empat elemen.

\section{Teori Stakeholder}

Teori stakeholder menjelaskan bahwa perusahaan harus memberikan manfaat bagi para stakeholdernya, tidak hanya beroperasi untuk pencapaian tujuannya. Stakeholder diartikan sebagai pemangku kepentingan yaitu pihak atau kelompok yang berkepentingan, baik langsung maupun tidak langsung terhadap eksistensi atau aktivitas perusahaan, dan karenanya kelompok tersebut mempengaruhi dan dipengaruhi oleh perusahaan. Kelompok stakeholder inilah yang menjadi pertimbangan utama bagi perusahaan dalam mengungkapkan atau tidak mengungkapkan suatu informasi di dalam annual report (Puspitasari, 2017).

\section{Fraud}

Fraud merupakan istilah yang umum dikalangan para akuntan, auditor, investor, dan masyarakat yang bergerak di bidang ekonomi akuntansi. Fraud sendiri memiliki cakupan pengertian yang cukup luas. Menurut Thahjono (2013:23) Fraud didefinisikan sebagai tindakan ilegal atau melakukan kegiatan tidak semestinya yang disengaja dengan tujuan untuk mengelabui yang lain dimana korban menderita kerugian dan pelaku fraud memperoleh keuntungan.

\section{Sistem Pengendalian Internal}

Istilah pengendalian muncul kali pertama dalam kamus Bahasa Inggris sekitar tahun 1.600 dengan kata control yang berarti mengendalikan, sebagai kata kerja. Menurut Committee of Sponsoring Organization of the Tread way Commission (COSO, 2013) dalam laporan Internal ControlIntegrated Framew ork mendefinisikan pengendalian internalsebagai berikut: A process, effected by an entitty's board of directors, management, andother personnel, designed to provide reason nable assurance regarding theachivement of objectives relating to operations, reporting, and compliance. (Suatu proses, yang dirancang dan dilaksanakan oleh dewan, manajemen dan pegawai 
untuk memberikan kepastian yang memadai dalam mencapai objektivitas yang berkaitan dengan operasi, pelaporan, dan kepatuhan).

\section{Kesesuaian Kompensasi Finansial}

Menurut Sinambele (2016: 220) kompensasi merupakan total dari semua penghargaan yang diberikan pada pegawai sebagai imbalan atas jasa mereka terhadap organisasi atau wujud penghargaan yang diterima karyawan sebagai pengganti kontribusi jasa pada perusahaan. Kompensasi merupakan biaya utama atas keahlian atau pekerjaan dalam bisnis perusahaaan. Bentuk kompensasi yang mencangkup berbagai macam penghargaan biasanya diterima secara langsung dan tidak langsung oleh pegawai. Kompensasi finansial langsung (direct financial compensation) terdiri dari bayaran yang diterima orang dalam bentuk upah, gaji, komisi dan bonus. Sedangkan kompensasi finansial tidak langsung (inderect financial compensation) terdiri dari semua reward finansial yang tidak dicakup dalam kompensasi langsung.

\section{METODE PENELITIAN}

\section{Jenis dan Sumber Data}

Jenis data yang digunakan dalam penelitian ini adalah data primer. Sumber datanya diperoleh melalui penyebaran kuesioner pada karyawan Perusahaan Air Minum Tirta Mangkaluku Kota Palopo. Dengan cara menjawab item-item pertanyaan dalam kuesioner yang mewakili variabelvariabel yang akan diukur.

\section{Populasi dan Sampel}

Kuntjojo (2009: 29) Populasi adalah jumlah keseluruhan dari satuan-satuan atau individu-individu yang karakteristiknya hendak diteliti. Dan satuan-satuan tersebut dinamakan unit analisis, dan dapat berupa orang-orang, institusi-institusi, benda-benda, dan seterusnya. Populasi dari penelitian ini adalah seluruh karyawan Perusahaan Air Minum Tirta Mangkaluku Daerah Kota Palopo yang berjumlah 292 karyawan.

Sampel atau contoh adalah sebagian dari populasi yang karakteristiknya hendak diteliti. Sampel terdiri atas sejumlah anggota yang dipilih dari populasi Kuntjojo (2009: 29). Sampel dari penelitian ini adalah sebagian karyawan yang ada pada Perusahaan Air Minum Tirta Mangkaluku Daerah Kota Palopo. Adapun cara penentuan jumlah sampel yaitu dengan menggunakan rumus Slovin (Sapar, 2017: 53). 


$$
\mathrm{n}=\frac{N}{1+N e^{2}}
$$

Di mana:

$\mathrm{n} \quad=$ ukuran sampel

$\mathrm{N} \quad=$ ukuran populasi

$\mathrm{e}=$ persen kelonggaran ketidaktelitian (presisi) karena kesalahan Pengambilan sampel yang masih dapat ditolerir atau diinginkan.

\section{Metode Analisis Data}

Metode analisis data yang digunakan dalam penelitian ini adalah regresi linear berganda dengan bantuan software SPSS. Regresia linear berganda adalah mencari pengaruh antara satu variabel dependen dan dua atau lebih variabel independent. Oleh karena itu regresi berganda merupakan metode yang akan meneliti ada atau tidaknya hubungan antara satu kejadian dengan sejumlah kejadian yang lain.

Rumus Regresi Linear Berganda adalah:

$$
\mathrm{Y}=\mathrm{a}+\beta_{1} \mathrm{X}_{1}+\beta_{2} \mathrm{X}_{2}+\mathrm{e}
$$

Dimana :

$$
\begin{array}{ll}
\mathrm{Y} & =\text { Kecenderungan Fraud } \\
\mathrm{a} & =\text { Konstanta } \\
\beta & =\text { Koefisien regresi } \\
\mathrm{X}_{1} & =\text { Sistem Pengendalian Internal } \\
\mathrm{X}_{2} & =\text { Kesesuaian Kompensasi Finansial } \\
\mathrm{e} & =\text { Error }
\end{array}
$$

\section{HASIL DAN PEMBAHASAN}

\section{Hasil Penelitian}

Uji Hipotesis dalam penelitian ini menggunakan analisis regresi linear berganda yang meliputi uji koefisien determinasi $\left(\mathrm{R}^{2}\right.$ ), uji persial (uji t) dan uji simultan (uji F) pengujian ini dilakukan untuk menguji hubungan antar variabel penelitian, mengetahui besarnya pengaruh masing-masing variabel bebas terhadap variabel terikat dan mengetahui apakah seluruh variabel bebas mempunyai pengaruh secara bersama-sama terhadap variabel terikat. Ringkasan hasil analisis regresi linear berganda disajikan pada tabel 4.6 dibawah ini. 
Tabel 4.6

\section{Ringkasan Hasil Uji Analisis Regresi Linear Berganda}

\begin{tabular}{|c|c|c|c|}
\hline \multicolumn{4}{|c|}{$\mathrm{Y}=7,875+0,348 \mathrm{X} 1+0,322 \mathrm{X} 2$} \\
\hline & Coefficient & t-statistic & $\mathrm{Sig}$ \\
\hline Konstanta & 7,875 & 2,023 & 047 \\
\hline Sistem Pengendalian & & & \\
\hline Internal & ,348 & 3,299 & 002 \\
\hline Kesesuaian Kompensasi & & & \\
\hline Finansial & ,322 & 4,062 & 000 \\
\hline $\begin{array}{l}N=65 \\
R^{2}=, 306 \\
\text { Adj. } R^{2}=, 284 \\
\text { F-Statistic = 13,697 Sig. } \\
\text { Sumber : Hasil Pengolah }\end{array}$ & $\begin{array}{l}=, 000^{\mathrm{b}} \\
\text { an SPSS Tah }\end{array}$ & & \\
\hline
\end{tabular}

\section{Analisis Regresi Linear Berganda}

Analisis regresi linear berganda digunakan untuk menghitung besarnya pengaruh antara variabel independen yaitu sistem pengendalian internal dan kesesuaian kompensasi finansial terhadap variabel dependen yaitu kecenderungan fraud. Dari tabel 4.6 dapat dilihat model persamaan regresi berganda dengan menggunakan SPSS yaitu Unstandardized Coefficients, Hal tersebut akan dianalisis sesuai penjelasan berikut ini:

a. Nilai konstanta untuk persamaan regresi berdasarkan perhitungan statistik di atas sebesar sebesar 7,875 artinya apabila variabel bebas bernilai nol maka kecenderungan fraud pada PDAM Tirta Mangkaluku Kota Palopo tetap sebesar 7,875.

b. Nilai koefisien $\left(\beta_{1}\right)$ sebesar 0,348 menunjukkan bahwa pengaruh pengendalian internal $\left(\mathrm{X}_{1}\right)$ terhadap kecenderungan fraud $\quad(\mathrm{Y})$ adalah positif atau searah, artinya setiap penigkatan variabel pengendalian internal sebesar satu satuan, maka kecenderungan fraud akan mengalami kenaikan sebesar 0,348 satuan.

c. Nilai koefisien $\left(\beta_{2}\right)$ sebesar 0,322 menunjukkan bahwa kesesuaian kompensasi finansial $\left(\mathrm{X}_{2}\right)$ terhadap kecenderungan fraud $\quad(\mathrm{Y})$ adalah positif atau searah, artinya setiap peningkatan variabel kesesuaian kompensasi finansial sebesar satu satuan, maka kecenderungan fraud akan mengalami kenaikan sebesar 0,322 satuan.

\section{Pembahasan}

\section{Pengaruh Pengendalian Internal terhadap Kecenderungan Fraud.}

Berdasarkan analisis hasil penelitian menunjukkan bahwa pengendalian internal terhadap kecendrungan fraud. Dalam pengujian secara parsial (Uji t) menunjukkan bahwa, variabel sistem 
pengendalian internal berpengaruh secara positif dan signifikan terhadap kecenderungan fraud di Perusahaan Daerah Air Minum Tirta Mangkaluku Kota Palopo, hal ini terlihat dari pengujian hipotesis dengan nilai probabilitasnya yaitu signifikan sebesar $0,002<0,05$ dan nilai $t$ hitung $(3,299)$ $>t$ tabel $(1,669)$. Kondisi ini menggambarkan bahwa semakin kuat dan tinggi sistem pengendalian internal yang dimiliki perusahaan maka akan semakin berpengaruh terhadap kecenderungan fraud pada perusahaan tersebut.

Hasil penelitian ini sejalan dengan teori yang dikemukakan oleh Rahayu (2013:221) pengendalian internal adalah suatu proses, yang dipengaruhi oleh dewan komisaris, manajemen, dan personel lainya dalam suatu entitas, yang dirancang untuk memberikan keyakinan memadai guna mencapai tujuan yaitu: (a) keandalan laporan keuangan, (b) menjaga kekayaan dan catatan organisasi, (c) kepatuhan terhadap hukum dan peraturan dan (d) efektifitas dan efisiensi operasi. Hal ini menunjukkan bahwa semakin baik pengendalian internal di suatu instansi maka dapat menurunkan tingkat kecenderungan fraud. Sistem pengendalian internal dalam Perusahaan Daerah Air Minum Tirta Mangkaluku Kota Palopo telah mencapai tujuan dalam kepatuhan hukum dan peraturan, efektifitas dan efisiensi operasi perusahaan. Tercapainya tujuan perusahaan dikarenakan memiliki sistem pendendalian internal yang baik yang memungkinkan pencegahan kecenderungan fraud.

Stakeholder juga berperan dalam tercapainya tujuan pengendalian. Menurut Puspitasari (2017) Stakeholder diartikan sebagai pemangku kepentingan yaitu pihak atau kelompok yang berkepentingan, baik langsung maupun tidak langsung terhadap eksistensi atau aktivitas perusahaan, dan karenanya kelompok tersebut mempengaruhi dan dipengaruhi oleh perusahaan.

Hasil penelitian ini sejalan dengan penelitian terdahulu yang dilakukan oleh Ramadhany (2017), Frilia (2015) dan Radhiah (2016) yang melihat pengaruh pengendalian internal terhadap kecenderungan fraud. Hasil penelitian mereka menunjukkan bahwa semakin efektif pengendalian internal maka semakin kecil kecenderungan terjadinya kecurangan. Namun penelitian ini tidak sejalan dengan hasil penelitian yang dilakukan oleh Prayoga (2017) Hasil penelitiannya membuktikan bahwa sistem pengendalian internal berpengaruh negatif dan tidak signifikan terhadap kecenderungan fraud. Ini terjadi karena belum efektifnya sistem pengendalian internal yang di tetapkan sehingga tata kelola perusahaan yang tidak baik dapat tercapai yang mengakibatkan kecurangan. 


\section{Pengaruh Kesesuaian Kompensasi Finansial Terhadap Kecenderungan Fraud.}

Berdasarkan analisis hasil penelitian menunjukkan bahwa kesesuaian kompensasi finansial berpengaruh terhadap kecenderungan fraud. Dari hasil uji yang sama secara parsial (Uji t), variabel kompensasi juga berpengaruh secara positif dan signifikan terhadap kecenderungan fraud di Pemerintah Kota Palopo, hal ini terlihat dari nilai probabilitasnya yaitu $0,000<0,05$ dan nilai $\mathrm{t}$ hitung 4,062 > t tabel 1,669. Kondisi ini menggambarkan bahwa semakin rendah dan tinggi kompensasi finansial yang diterima perusahaan maka akan berpengaruh terhadap kecenderungan fraud pada perusahaan tersebut.

Hasil penelitian ini sejalan dengan penelitian terdahulu yang dilakukan oleh Tiro (2014), Radhiah (2016) dan Tarigan (2018) yang melihat pengaruh kompensasi terhadap kecenderungan fraud. Hasil penelitian mereka menunjukkan bahwa semakin tinggi tingkat kesesuain kompensasi maka semakin kecil kecenderungan terjadinya kecurangan. Namun penelitian ini tidak sejalan dengan hasil penelitian yang dilakukan oleh Aji (2018) Hasil penelitiannya membuktikan bahwa kesesuaian kompensasi finansial berpengaruh negatif dan tidak signifikan terhadap kecenderungan fraud. Ini terjadi jika suatu organisasi tidak menyediakan kompensasi yang sesuai, kecenderungan untuk melakukan kecurangan akan meningkat.

\section{PENUTUP}

\section{Simpulan}

Berdasarkan hasil analisis, pengujian hipotesis dan pembahasan yang telah dilakukan yaitu mengenai pengaruh pengendalian internal dan kesesuaian kompensasi finansial terhadap kecenderungan fraud pada Perusahaan Daerah Air Minum Daerah Kota Palopo maka dapat disimpulkan bahwa:

a. Pengendalian internal berpengaruh positif dan signifikan terhadap kecenderungan fraud pada Perusahaan Air Minum Tirta Mangkaluku Kota Palopo. Sehingga hipotesis pertama dinyatakan diterima.

b. Kompensasi berpengaruh berpengaruh positif dan signifikan terhadap kecenderungan fraud pada Perusahaan Air Minum Tirta Mangkaluku Daerah Kota Palopo. Sehingga hipotesis kedua dinyatakan diterima. 


\section{Saran}

Berdasarkan evaluasi dari keterbatasan yang ada atas hasil penelitian, beberapa saran yang diharapkan dapat menjadi bahan pertimbangan untuk peneliti selanjutnya, antara lain:

a. Penelitian selanjutnya dapat mengembangkan beberapa hal yakni memperluas obyek penelitian, dan menambahkan variabel lain yang diperkirakan mempengaruhi kecenderungan fraud seperti ketaatan hukum, komitmen organisasi, dan moralitas.

b. Hasil penelitian ini diharapkan dapat memberikan masukan bahwa pengendalian internal, dan kompensasi memiliki pengaruh yang signifikan terhadap tingkat kecenderungan kecurangan (Fraud). Bagi Perusahaan Air Minum Tirta Mangkaluku Daerah Kota Palopo diharapkan untuk dapat lebih mengefektifkan dan mengembangkan pengendalian internal (penerapan wewenang dan tangggung jawab, komunikasi dan informasi serta pengawasan dan evaluasi) dan pemberian kompensasi yang sesuai (khususnya gaji dan tunjangan) terhadap pegawai agar dapat menekan terjadinya praktek kecurangan.

c. Pengumpulan data pada penelitian selanjutnya diharapkan tidak hanya sebatas penyebaran kuesioner saja tetapi dapat juga dilakukan dengan pengamatan, dokumentasi, observasi serta wawancara langsung ke objek penelitian. Kehadiran peneliti pada saat responden melakukan pengisian kuesioner sebaiknya dilakukan, karena responden dapat menanyakan secara langsung butir-butir pernyataan yang tidak dipahami.

\section{DAFTAR PUSTAKA}

ACFE. 2014. Report to the nations on occupational fraud and abuse. (https://www.acfe.com/rttn/docs/2014-report-to-nations.pdf), (Diakses pada tanggal 12 Januari 2019).

Adi, Moh. Risqi Kurnia. 2016. Analisis Faktor-Faktor Penentu Kecurangan (Fraud) Pada Sektor Pemerintahan (studi kasus pada Dinas Pendapatan Pengelolaan Keuangan dan Aset Daerah Kota Pekalongan). Jurnal Litbang Kota Pekalongan, Vol: 10.

Aji, Seto Satriyo Bayu. 2018. The Determinants Affecting Fraud Trends. Asia Pasific Fraud Journal, Vol: 3, No: 1, (Januari-Juni 2018).

Alagraph.com. 7 januari 2019. ACC Launching Catatan Antikorupsi 2018: PNS Aktor Korupsi Terbanyak. (https://www.alagraph.com/berita/detail/acc-launching-catatan-antikorupsi2018-pns-aktor-korupsi-terbanyak), (Diakses tanggal 11 januari 2019).

Albrecht, W., et.al. 2012. Fraud Examination. Connecticut: Cengage Learning. 
Alou, Shelby Defiany, et al. 2017. Pengaruh Kesesuaian Kompensasi, Moralitas Manajemen, dan Keefektifan Pengendalian Internal Terhadap Kecenderungan Kecurangan Akuntansi Pada Perusahaan Konstruksi Di Manado. Jurnal Riset Akuntansi Going Concern, Vol: 12, No: 1.

Cendikia, Cita. 2016. Pengaruh Efektifitas Pengendalian Internal Dan Kesesuaian Kompensasi Terhadap Pencegahan Kecurangan (Fraud) Pada Pdam Tirta Siak Pekanbaru. Skripsi. Riau: Program Studi Pendidikan Ekonomi Fakultas Keguruan dan Ilmu Pendidikan Universitas Riau.

COSO. 2013. Internal Control-Integrated Framework. (https://home.kpmg/content/dam/kpmg/pdf/2016/05/2750-New-COSO 2013-FrameworkWhitepaper-V4.pdf), (Diakses pada tanggal 12 Januari 2019).

Cnnindonesia.com.19 Oktober 2015. Eks Wali Kota Makassar Didakwa Rugikan NegaraRp45,8Miliar.(https://www.cnnindonesia.com/nasional/20151019202500-1285904/eks-wali-kota-makassar-didakwa-rugikan-negara-rp-458-miliar),Diakses tanggal 22 Februari 2019).

Cressey, D. 1953. Other people's money: a study in the social psychology of embezzlement. Glencoe: Free Press.

Frilia, Figna. 2015. Pengaruh Asimetri Informasi, Sistem Pengendalian Intern, dan Kesesuaian Kompensasi terhadap Kecenderungan Kecurangan Akuntansi (Studi Empiris Pada Bank Swasta Di Kota Pekanbaru). Jom Fekon, Vol.2 No. 1, Februari 2015.

Hidayat, Zullaika. 2018. Pengaruh Budaya Etis Organisasi, Sistem Pengendalian Internal, Asimetri Informasi dan Kesesuaian Kompensasi terhadap Kecurangan (Persepsi Pegawai Dinas di Kabupaten Kepulauan Mentawai). Jom Feb, Vol: 1, (Januari - Juni 2018).

Irphani, Ardi. 2017. Pengaruh Tekanan, Keefektifan Sistem Pengendalian Internal, Perilaku Tidak Etis, dan Jabatan dalam Pengelola Keuangan terhadap Fraud (Studi Pada Satuan Kerja Perangkat Daerah Kota Metro). Tesis Bandar Lampung: Magister Ilmu Akuntansi Fakultas Ekonomi dan Bisnis Universitas Lampung.

Jusuf, Al. Haryono. 2014. Auditing: pengauditan berbasis ISA, edisi 2. Yogyakarta: Sekolah Tinggi Ilmu Ekonomi YKPN.

Karyono. 2013. Forensic fraud. Yogyakarta: C.V Andi Offset.

Kusumawati, Dewi. 2017. Pengaruh Stakeholder Engagement terhadap Pengungkapan Sustainability Report Berdasarkan Global Reporting Initiative (GRI) G4 (Studi Empiris Pada Perusahaan Non-Keuangan yang Terdaftar di BEI Tahun 2013-2015). Skripsi. Bandar Lampung: Fakultas Ekonomi dan Bisnis Universitas Lampung.

Kuntjojo. 2009. Metodologi Penelitian. Kediri.

Muna, Biaini Naeli dan Lutfi Harris. 2018. Pengaruh Pengendalian Internal dan Asimetri Informasi terhadap Kecenderungan Kecurangan Akuntansi (Penelitian Persepsi Pengelola Keuangan 
pada Perguruan Tinggi Negeri BLU). Jurnal Akuntansi, Ekonomi Dan Manajemen Bisnis, Vol: 6, No: 1, Juli 2018.

Newsdetik.com. 22 Februari 2018. Indeks Persepsi Korupsi 2017, Indonesia Peringkat Ke96.(https://n/berita/3879592/indeks-persepsi-korupsi-2017-indonesia peringkat-ke-96), (Diakses tanggal 11 Januari 2019).

Peraturan Pemerintah Republik Indonesia No. 8 Tahun 2006 tentang Sistem Pengendalian Internal Pemerintah. 2006. Jakarta: Departemen Keuangan Republik Indonesia.

Prayoga, Fajar Nato dan Intan Pramesti Dewi. 2017. Pengaruh Pengendalian Internal dan Kompensasi terhadap Kecurangan (Fraud) (Studi Kasus Pada Pt.Bank Mandiri (Persero) Tbk. Area Asia Afrika Kota Bandung). Jurnal Sains Manajemen \& Akuntansi, Vol: 11, No: 2, November 2017.

Priyono dan Marnis. 2008. Manajemen Sumber Daya Manusia. Sidoarjo: Zifatama Publisher.

Puspitasari, Ayudia Dwi. 2017. Analisis Pengaruh Enterprise Risk Management Disclosure, Intellectual Capital Disclosure, dan Corporate Social Responsibility Disclosure Terhadap Nilai Perusahaan(Studi Empiris Pada Perusahaan Pertambangan yang Terdaftar di BEI Tahun 2012-2015). Skripsi. Bandar Lampung: Fakultas Ekonomi Dan Bisnis Universitas Lampung.

Radhiah, Tia. 2016. Pengaruh Efektifitas Pengendalian Internal, Kesesuaian Kompensasi, dan Moralitas Individu terhadap Kecenderungan Kecurangan Akuntansi (Studi Kasus Pada Pt. Pos Indonesia Kcu Kota Pekanbaru). Jom Fekon, Vol: 3, No: 1, Februari 2016.

Rahayu, Siti Kurnia dan Ely Suhayati. 2013. Auditing: konsep dasar dan pedoman pemeriksaan akuntan publik. Yogyakarta: Graha Ilmu.

Ramadhany, Indra. 2017. Pengaruh Sistem Pengendalian Intern, Asimetri Informasi, Kesesuaian Kompensasi dan Implementasi Good Corporate Governance terhadap Kecenderungan Kecurangan Akuntansi (Studi Empiris pada Rumah Sakit Swasta yang ada di Pekanbaru). Jom Fekon, Vol. 4 No.1, Februari 2017.

Romney, Marshall B, dan Paul John Steinbart. 2017. System informasi akuntansi, edisi 13. Jakarta: Salemba Empat.

Rivai dan Ella Jauvani. 2010. ManajemenSumber Daya Manusia Untuk Perusahaan. Jakarta: Raja Grafindo Persada.

Sapar. 2017. Pengantar Metode Penelitian. Bogor: Makaira Printing Plus.

Setiawan MM, Toni. 2012. Manajemen Sumber Daya Manusia: Kinerja, Motivasi, Kepuasan Kerja danProduktivitas, edisi 1. Jakarta: Platinum.

Shintadevi, Prekanida Farizqa. 2015. Pengaruh Keefektifan Pengendalian Internal, Ketaatan Aturan Akuntansi dan Kesesuaian Kompensasi terhadap Kartini Wulandari $12 \mid 13$ 
Kecenderungan Kecurangan Akuntansi dengan Perilaku Tidak Etis sebagai Variabel Intervening. Jurnal Nominal, Vol: 6, No:2, Tahun 2015.

Sinambela, lijan Poltak. 2016. Manajemen Sumber Daya Manusia. Jakarta: PT Bumi Aksara.

Sugito, Yogi. 2013. Metodologi penelitian. Malang: Universitas Brawijaya Press (UB Press).

Sugiyono. 2012. Metode Penelitian Bisnis. Bandung : Alfabeta.

Tarigan, Rahmat Syahputra, et al. 2018. Analisis Faktor Faktor Yang Mempengaruhi Tindakan Kecurangan (Studi Empiris Pada Perusahaan Swasta Perkebunan Kelapa Sawit Di Riau). Jurnal Ekonomi, Vol:26, No: 1, Maret 2018.

Thahjono, Subagio, et al. 2013. Business crime and Ethics: konsep dan studi kasus fraud di Indonesia dan global. Yogyakarta: CV Andi Offset.

Tiro, Andi Amirullah Arif. 2014. Pengaruh Pengendalian Internal dan Kompensasi terhadap Kecenderungan Kecurangan (Fraud) Pada Pemerintah Kota Palopo. Skipsi. Makassar: Fakultas Ekonomi dan Bisnis Universitas Hasanuddin.

Tuanakotta, Theodorus M. 2014. Audit Berbasis ISA (international Standards on Auditing. Jakarta: Selemba Empat.

Udayani, Anak Agung K. Finty dan Maria M. Ratna Sari. 2017. Pengaruh Pengendalian Internal dan Moralitas Individu pada Kecenderungan Kecurangan Akuntansi. E-Jurnal Akuntansi Universitas Udayana, Vol: 18, Maret 2017.

Usmar, Dani dan Ivan Adhitrya Nurfadillah. 2016. Pengaruh Efektifitas Pengendalian Internal terhadap Kecurangan Akuntansi pada PT. Inka Mutiara Mas. Jurnal Wawasan dan Riset Akuntansi, Vol: 4, No. 1, September 2016.

Wolfe, David.T dan Dana R. Hermanson. 2004. The Fraud Diamond: considering the four Elements of fraud. The CPA Journal. 